\title{
Model for Economic Analysis of Fungicide Usage in Hybrid Corn Seed Production
}

\author{
S. N. Wegulo, Graduate Research Assistant, C. A. Martinson, Associate Professor, J. M. Rivera-C., former \\ Graduate Research Assistant, and F. W. Nutter, Jr., Associate Professor, Department of Plant Pathology, Iowa State \\ University, Ames 50011
}

\begin{abstract}
Wegulo, S. N., Martinson, C. A., Rivera-C., J. M., and Nutter, F. W., Jr. 1997. Model for economic analysis of fungicide usage in hybrid corn seed production. Plant Dis. 81:415-422.

A model was used to determine the economic benefits of using fungicides to control foliar diseases of seed corn. The components of the model were (i) increased net return to the seed company from fungicide usage, (ii) increased income, based on a wholesale price of $\$ 30$ per unit of 80,000 seeds and a premium of $\$ 2$ per unit of medium-sized seed, and (iii) increased expenses, calculated as the sum of fungicide and fungicide application costs, cost of processing increased seed, and increased payment to the grower by the seed company. Increased payment to the grower was calculated as the product of increased seed yield (before separation into fractions), May futures price for no. 2 commercial corn on 1 March, and an average inbred production factor. Increased net return was calculated by subtracting increased expenses from increased income. Yield data were obtained from fungicide trial experiments in commercial hybrid corn seed production fields in Iowa from 1990 to 1993. Of 169 fungicide treatments applied, 64 and $79 \%$ were profitable to the seed company and to the grower, respectively. The results from this study indicate that fungicide usage in hybrid corn seed production can be economically beneficial.
\end{abstract}

Additional keywords: Aureobasidium zeae, Bipolaris zeicola, Cercospora zeae-maydis, Exserohilum turcicum, Puccinia sorghi
The commercial yellow dent corn crop in the United States is produced entirely from hybrid seed. Currently, U.S. hybrid corn seed production occupies between 750,000 and 800,000 acres $(303,000$ and 324,000 ha) (2). Various studies have shown that foliar fungal diseases of corn can cause considerable crop loss $(1,16,18$, 19). Crop loss occurs because foliar diseases remove photosynthetic leaf area, which reduces both net amount of radiation intercepted and radiation use efficiency $(11,14)$ and may also impair translocation of photosynthates to the developing ear. These negative effects of pathogens cause a reduction in the accumulation of dry matter in seed, which results in reduced yield.

Several studies have demonstrated the efficacy of fungicides in controlling corn

Corresponding author: S. N. Wegulo

E-mail: wegulo@iastate.edu

Journal paper J-16516 of the Iowa Agriculture and 2646 and 3116. Portion of an M.S. thesis by S. N. Wegulo submitted to the Graduate College, Iowa State University. This research was funded in part by USDA-CSRS North Central Region Pesticide Impact Assessment grant 553.

Accepted for publication 31 January 1997.

Publication no. D-1997-0228-05R

(C) 1997 The American Phytopathological Society Home Economics Experiment Station projects diseases and in increasing yield $(4,17,19)$. Successful control is dependent on the choice of fungicide, application timing and frequency, and coverage of foliage (7). Chlorothalonil, copper thallate, and mancozeb are broad-spectrum, foliage-protectant fungicides registered for use on seed corn in the United States. Propiconazole, a systemic fungicide, was approved recently for use in corn production.

Foliar fungal diseases of corn are prevalent in the Midwest and include common rust (Puccinia sorghi Schwein.), gray leaf spot (Cercospora zeae-maydis Tehon \&
E.Y. Daniels), northern corn leaf blight (Exserohilum turcicum (Pass.) K.J. Leonard \& E.G. Suggs, syn. Helminthosporium turcicum Pass.), northern leaf spot (Bipolaris zeicola (G.L. Stout) Shoemaker, syn. Helminthosporium carbonum Ullstrup), and eyespot (Aureobasidium zeae (Narita \& Hiratsuka) J.M. Dingley, syn. Kabatiella zeae Narita \& Hiratsuka). These diseases can be controlled with fungicides $(7,12)$.

Corn diseases have a high degree of spatial and temporal variability (6). This variability causes uncertainty in making decisions about control measures (such as use of fungicides). This uncertainty is compounded by disease and financial risks. Often the levels of these risks are unknown to the seed company or the grower at the time the decision to apply control measures is made because the specific diseases that may occur during the growing season, their intensities, rate of development, and economic damage cannot be predicted with a high degree of certainty. Knowledge about the expected economic returns from use of fungicides to control foliar diseases of seed corn would benefit producers by enabling them to make more informed decisions, thereby improving the chance of making a profit.

Seed corn is a high-value crop, currently selling at an average wholesale price of about $\$ 30$ per unit of 80,000 seeds. Therefore, the use of foliar fungicides to reduce crop loss in hybrid corn seed production may be economically feasible whenever disease levels exceed damage thresholds
Table 1. Growth stages (GS) of corn and their identifying characteristics used in fungicide experiments in hybrid corn seed production fields in Iowa, 1990 to $1992^{z}$

\begin{tabular}{ll}
\hline Growth stage & Identifying characteristics \\
\hline Vegetative stage & \\
GS 0.0 & Plant emergence; tip of coleoptile visible at soil surface \\
GS 1.0 & Collar of 4th leaf visible \\
GS 2.0 & Collar of 8th leaf visible \\
GS 3.0 & Collar of 12th leaf visible \\
GS 4.0 & Collar of 16th leaf visible \\
Reproductive stage & 50\% of plants have visible silks \\
GS 5.0 & Ears have most kernels in "blister" stage \\
GS 6.0 & Ears have most kernels in "soft dough" stage \\
GS 7.0 & In some ears, kernels start denting \\
GS 8.0 & Kernels fully dented \\
GS 9.0 & Black layer formation; physiological maturity reached, and dry matter \\
GS 10.0 & accumulation ceased \\
\hline
\end{tabular}

\footnotetext{
${ }^{\mathrm{z}}$ Modified from Hanway (9). For the identification of transition phases between stages, the interval
} was arbitrarily divided into three substages equally spaced in time and identified as $0.2,0.5$, and 0.8 . 
(15). Experimental data to quantify the economic benefits of fungicide usage in hybrid corn seed production are lacking, and decisions by seed companies and growers about when to apply fungicides are mainly subjective. Moreover, inbred lines are at greater risk of yield reduction than commercial hybrids because detassel-
Table 2. Fungicide sprays (X, Y, and Z) applied to experimental plots in Iowa commercial hybrid corn seed production fields $90 \mathrm{~A}$ and $\mathrm{B}(\mathrm{X})$ and $90 \mathrm{C}$ and $\mathrm{D}(\mathrm{Y})$ in 1990; fields $91 \mathrm{~A}$ through $\mathrm{D}(\mathrm{X})$ in 1991; and fields 92 A through D (X) and $92 \mathrm{E}(\mathrm{Z})$ in 1992

\begin{tabular}{|c|c|c|c|c|c|c|c|c|}
\hline \multirow{2}{*}{$\begin{array}{l}\text { Year } \\
\text { Fungicide }\end{array}$} & \multirow{2}{*}{$\begin{array}{c}\text { Dosage } \\
\text { (lb a.i./acre) }\end{array}$} & \multicolumn{7}{|c|}{ Growth stage } \\
\hline & & 2.5 & 4.0 & 5.0 & 5.5 & 6.0 & 6.8 & 7.0 \\
\hline \multicolumn{9}{|l|}{1990} \\
\hline \multirow[t]{2}{*}{ Chlorothalonil } & 2.26 & $\ldots$ & $\ldots$ & $\mathrm{X}^{\mathrm{w}}$ & $\ldots$ & $X Y^{x}$ & $\ldots$ & $\mathrm{Y}$ \\
\hline & 2.26 & $\ldots$ & $\ldots$ & $\ldots$ & $\ldots$ & $X-$ & $\ldots$ & $\mathrm{Y}$ \\
\hline \multirow[t]{2}{*}{ Copper thallate } & 1.84 & $\ldots$ & $\ldots$ & $\mathrm{X}$ & $\ldots$ & $X Y$ & $\ldots$ & $\mathrm{Y}$ \\
\hline & 1.84 & $\cdots$ & $\cdots$ & $\cdots$ & $\ldots$ & $\mathrm{X}-$ & $\cdots$ & Y \\
\hline \multirow[t]{2}{*}{ Propiconazole } & 0.11 & $\ldots$ & $\ldots$ & $\mathrm{X}$ & $\ldots$ & $X Y$ & $\ldots$ & $\mathrm{Y}$ \\
\hline & 0.11 & $\ldots$ & $\ldots$ & $\ldots$ & $\ldots$ & $X-$ & $\ldots$ & $\mathrm{Y}$ \\
\hline Untreated & 0.00 & $\ldots$ & $\ldots$ & $\ldots$ & $\ldots$ & $\ldots$ & $\ldots$ & $\cdots$ \\
\hline \multicolumn{9}{|l|}{1991} \\
\hline \multirow[t]{4}{*}{ Chlorothalonil } & 1.51 & $\ldots$ & $\mathrm{X}$ & $\ldots$ & $\mathrm{X}$ & $\ldots$ & $X$ & $\ldots$ \\
\hline & 1.51 & $\ldots$ & $X$ & $\ldots$ & $X$ & $\ldots$ & $\ldots$ & $\ldots$ \\
\hline & 1.51 & $\ldots$ & $\ldots$ & $\ldots$ & $X$ & $\ldots$ & $\mathrm{X}$ & $\ldots$ \\
\hline & 2.26 & $\ldots$ & $\mathrm{X}$ & $\ldots$ & $X$ & $\ldots$ & $\ldots$ & $\ldots$ \\
\hline Propiconazole & 0.11 & $\ldots$ & $\mathrm{X}$ & $\cdots$ & $\mathrm{X}$ & $\ldots$ & $\ldots$ & $\ldots$ \\
\hline Propiconazole & 0.11 & $\ldots$ & $\mathrm{X}$ & $\ldots$ & $\mathrm{X}$ & $\ldots$ & $\ldots$ & $\ldots$ \\
\hline + chlorothalonil & 1.51 & $\cdots$ & $\cdots$ & $\cdots$ & $\cdots$ & $\cdots$ & $\mathrm{X}$ & $\cdots$ \\
\hline Copper thallate & 1.84 & $\ldots$ & $\mathrm{X}$ & $\ldots$ & $\mathrm{X}$ & $\cdots$ & $\mathrm{X}$ & $\cdots$ \\
\hline Untreated & 0.00 & $\ldots$ & $\cdots$ & $\cdots$ & $\cdots$ & $\cdots$ & $\ldots$ & $\ldots$ \\
\hline \multicolumn{9}{|l|}{1992} \\
\hline \multirow[t]{6}{*}{ Chlorothalonil } & 1.51 & $\mathrm{X}^{\mathrm{y}}$ & $X Z^{Z}$ & . & $\mathrm{XZ}$ & $\ldots$ & $\ldots$ & $\mathrm{XZ}$ \\
\hline & 1.51 & $\mathrm{X}$ & $\mathrm{XZ}$ & $\ldots$ & $-Z$ & $\ldots$ & $\ldots$ & $\ldots$ \\
\hline & 1.51 & $\ldots$ & $\mathrm{X}-$ & $\ldots$ & $\mathrm{XZ}$ & $\ldots$ & $\ldots$ & $-Z$ \\
\hline & 1.51 & $\ldots$ & $-\mathrm{Z}$ & $\ldots$ & $X-$ & $\ldots$ & $\ldots$ & $X-$ \\
\hline & 1.51 & $\ldots$ & $X-$ & $\ldots$ & $-Z$ & $\ldots$ & $\ldots$ & $\ldots$ \\
\hline & 1.51 & $\ldots$ & $\ldots$ & $\ldots$ & $X-$ & $\ldots$ & $\ldots$ & $\ldots$ \\
\hline Mancozeb & 1.12 & $X$ & $\mathrm{XZ}$ & $\ldots$ & $\mathrm{XZ}$ & $\ldots$ & $\ldots$ & $\mathrm{XZ}$ \\
\hline \multirow[t]{2}{*}{ Propiconazole } & 0.11 & $\mathrm{X}$ & $\mathrm{XZ}$ & $\cdots$ & $-Z$ & $\ldots$ & $\ldots$ & $\cdots$ \\
\hline & 0.11 & $\ldots$ & $X-$ & $\ldots$ & $\ldots$ & $\ldots$ & $\ldots$ & $\cdots$ \\
\hline Propiconazole & 0.11 & $\ldots$ & $-Z$ & $\cdots$ & $\cdots$ & $\cdots$ & $\cdots$ & $\cdots$ \\
\hline + chlorothalonil & 1.51 & $\cdots$ & & & $-\mathrm{Z}$ & $\cdots$ & $\ldots$ & $\cdots$ \\
\hline Untreated & 0.00 & $\ldots$ & $\ldots$ & $\ldots$ & $\ldots$ & $\ldots$ & $\ldots$ & $\ldots$ \\
\hline
\end{tabular}

wAt fields $90 \mathrm{~A}$ and B in 1990, the first and second fungicide sprays (X) were applied at growth stages (GS) 5.0 and 6.0, respectively.

${ }^{x}$ At fields $90 \mathrm{C}$ and D in 1990, the first and second fungicide sprays (Y) were applied at GS 6.0 and 7.0 , respectively.

${ }^{y}$ At fields 92 A through D in 1992, the first, second, third, and fourth fungicide sprays (X) were applied at GS 2.5, 4.0, 5.5, and 7.0, respectively.

${ }^{\mathrm{z}}$ At field $92 \mathrm{E}$ in 1992, the first, second, and third fungicide sprays (Z) were applied at GS 4.0, 5.5, and 7.0, respectively.

Table 3. Fungicide sprays (X) applied to experimental plots in commercial hybrid corn seed production fields 93 A through $\mathrm{H}$ in Iowa, 1993

\begin{tabular}{|c|c|c|c|c|c|c|}
\hline \multirow[b]{2}{*}{ Treatment } & \multirow{2}{*}{$\begin{array}{c}\text { Dosage } \\
\text { (lb a.i./acre) }\end{array}$} & \multicolumn{5}{|c|}{ Application schedule ${ }^{\mathrm{z}}$} \\
\hline & & 1 & 2 & 3 & 4 & 5 \\
\hline \multirow{5}{*}{ Chlorothalonil } & 1.51 & $\mathrm{X}$ & $X$ & $\mathrm{X}$ & $\mathrm{X}$ & $\mathrm{X}$ \\
\hline & 1.51 & $\mathrm{X}$ & $\mathrm{X}$ & $\ldots$ & $\ldots$ & $\ldots$ \\
\hline & 1.51 & $\ldots$ & $\mathrm{X}$ & $\mathrm{X}$ & $\ldots$ & $\ldots$ \\
\hline & 1.51 & $\ldots$ & $\mathrm{X}$ & $\ldots$ & $\ldots$ & $\ldots$ \\
\hline & 1.51 & $\ldots$ & $\mathrm{X}$ & $\mathrm{X}$ & $\mathrm{X}$ & $\ldots$ \\
\hline Mancozeb & 1.12 & $\mathrm{X}$ & $\mathrm{X}$ & $\mathrm{X}$ & $\ldots$ & $\ldots$ \\
\hline \multirow[t]{2}{*}{ Propiconazole } & 0.11 & & $\mathrm{X}$ & $\ldots$ & $\ldots$ & $\ldots$ \\
\hline & 0.11 & $\mathrm{X}$ & $X$ & $\ldots$ & $\ldots$ & $\ldots$ \\
\hline Propiconazole & 0.11 & $\mathrm{X}$ & $X$ & $\ldots$ & $\ldots$ & $\ldots$ \\
\hline+ mancozeb & 1.12 & $\mathrm{X}$ & $\mathrm{X}$ & $\mathrm{X}$ & $\ldots$ & $\ldots$ \\
\hline Untreated & 0.00 & $\ldots$ & $\ldots$ & $\ldots$ & $\ldots$ & $\ldots$ \\
\hline
\end{tabular}

${ }_{\mathrm{z}} 1$ = first spray, 7 to 13 days before the second spray; 2 = second spray, just before detasseling; $3=$ third spray, just after detasseling; $4=$ fourth spray, 10 to 13 days after the third spray; and $5=$ fifth spray, 10 to 11 days after the fourth spray. ing seed parent inbred lines removes a significant amount of leaf area and the additional reduction in healthy leaf area caused by disease will have a greater negative effect on yield $(5,25)$.

During recent years, growers have increasingly adopted minimum- or no-tillage practices to reduce soil erosion. These practices may increase levels of primary inoculum during intercrop periods (23). Increased levels of primary inoculum and inbred lines that are more susceptible than hybrids (2) to foliar fungal diseases may contribute to a need for increased use of fungicides in hybrid corn seed production. Hence, there is a need for quantitative information concerning the economics of using fungicides to control foliar fungal diseases in hybrid corn seed production. The purpose of this study was to develop a model to evaluate and compare the economic benefits of using different fungicides and schedules of application to manage foliar fungal diseases of seed corn in Iowa.

\section{MATERIALS AND METHODS}

Because English units are used in the U.S. grain trade and seed industry, we present our measurements and results in those units. Metric equivalents (mainly SI) are presented in the text in parentheses, but tables of results are presented only in English units. We present two versions of our economic model, one in which English units can be used and an SI version for international readers.

Field trials. Experiments were conducted in Iowa commercial hybrid corn seed production fields from 1990 to 1993 on land planted to corn the previous production year. Corn debris provided the initial inoculum for diseases incited by $A$. zeae, B. zeicola, C. zeae-maydis, and E. turcicum. Experiments were conducted in different geographical areas in Iowa during 1990 (Henry, Jefferson, Mahaska, and Marshall Counties), 1991 (Cedar and Mahaska Counties), 1992 (Benton, Grundy, and Marshall Counties), and 1993 (Benton, Grundy, Marshall, Story, and Webster Counties). The inbreds planted were: inbred 1 (fields $90 \mathrm{~A}, 90 \mathrm{~B}, 91 \mathrm{~A}, 91 \mathrm{~B}$, and 92 A through D); inbred 2 (fields $90 \mathrm{C}$, $90 \mathrm{D}, 91 \mathrm{C}$, and $91 \mathrm{D}$ ); inbred 3 (field 92 E); inbred 4 (fields $93 \mathrm{~A}$ and $\mathrm{B}$ ); inbred 5 (fields $93 \mathrm{C}$ and D); inbred 6 (fields $93 \mathrm{E}$ and $\mathrm{F}$ ); and inbred 7 (fields $93 \mathrm{G}$ and $\mathrm{H}$ ). During 1990 to 1992, fungicide sprays were timed to coincide with specific growth stages (GS) ranging from GS 2.5 to GS 7.0 (Table 1) (9). In 1993, the first, second, and third applications were made approximately 7 to 14 days before detasseling, immediately before detasseling, and immediately after detasseling. The fourth and fifth sprays were applied at approximately 10-day intervals after the third spray. Fungicide dosage and application schedules are given in Tables 2 and 3 . Latron-B 1956, a spreader-sticker, was 
added to mancozeb at 2.1 fluid ounces per acre (0.15 liter/ha) at each site.

Experimental units were plots $36 \mathrm{ft}$ $(11 \mathrm{~m})$ long and four rows wide of seed parent inbred corn plants. The four rows of seed parent inbred plants in each plot alternated with one row of pollen parent inbred plants. Treatments were arranged in a randomized complete block design with four replications. Row spacing was 30 in. $(0.76 \mathrm{~m})$. Fungicide application equipment consisted of a four-row spray boom with three TXVS-3 Conejet nozzles (Spraying Systems, Wheaton, IL) per row. A motorized backpack sprayer (model SHR-200E, ECHO, Northbrook, IL) powered the boom. One nozzle was positioned approximately 6 in. $(0.15 \mathrm{~m})$ above each row, and two nozzles were each attached to 15 -in. $(0.38 \mathrm{~m})$ hose drops (Spraying Systems) positioned midway between rows and directed at an angle to obtain maximum coverage of foliage. The boom extended over six rows (the four sprayed seed parent rows and one unsprayed pollen parent row on each side) and was carried by two persons who each held one end of the spray boom and walked at a timed pace of 1 mile $/ \mathrm{h}(0.44 \mathrm{~m} / \mathrm{s})$ to deliver approximately 30 gallons per acre (341 liters/ha) of fungicide spray at $60 \mathrm{lb} / \mathrm{in}^{2}(414 \mathrm{kPa})$.

Disease assessments were based on (i) a subjective disease injury index on a 0 to 9 scale, in which $0=$ no visible disease symptoms and $9=$ very severe damage deter-

mined from visual estimates of disease on foliage at defined growth stages, (ii) visual estimates of the percentage of leaf area diseased (\% LAD) at defined growth stages, or (iii) area under the disease progress curve (AUDPC). In all cases, five or six seed parent inbred plants were arbitrarily selected from the middle two rows of each plot, excluding plants within $1.6 \mathrm{ft}(0.5 \mathrm{~m})$ at either end of each row. Disease lesions were counted, or the percentage of the ear leaf and the two leaves immediately above and below the ear leaf covered with lesions was estimated with the aid of standard area diagrams (10). AUDPC was approximated by trapezoidal integration (20). Standardized (relative) AUDPC values were obtained by dividing AUDPC values by the total time duration (days) of each epidemic (8).

At maturity, ears from the middle $33 \mathrm{ft}$ $(10 \mathrm{~m})$ of the seed parent rows in each plot were harvested by hand and immediately delivered to the respective cooperating seed companies (Pioneer Hi-Bred International, ICI Seeds, and Lynks Seeds) for drying, shelling, weighing, and sizing. Seed samples weighing $17.6 \mathrm{oz}(0.5 \mathrm{~kg})$ were sized by the seed companies or at Iowa State University into the following categories: (i) large (passed through a 24/64-in.-hole [0.95 cm in diameter] screen and retained on a 22/64-in.-hole $[0.87 \mathrm{~cm}$ in diameter] screen), (ii) medium (passed a 22/64-in.-hole screen and retained on a 20/64-in.-hole $[0.79 \mathrm{~cm}$ in diameter]

Table 4. Fungicide prices and application costs (\$/acre) used in economic analysis of fungicide usage in experimental plots in commercial hybrid corn seed production fields in Iowa, 1990 to 1993

\begin{tabular}{lccc}
\hline Fungicide & $\begin{array}{c}\text { Price of } \\
\text { fungicide }\end{array}$ & $\begin{array}{c}\text { Cost per } \\
\text { application }\end{array}$ & $\begin{array}{c}\text { Total } \\
\text { cost }\end{array}$ \\
\hline Chlorothalonil & 13.10 & 5.00 & 18.10 \\
Copper thallate & 3.66 & 5.00 & 8.66 \\
Mancozeb & 4.05 & 5.00 & 9.05 \\
Propiconazole & 9.54 & 5.00 & 14.54 \\
\hline
\end{tabular}

screen), (iii) small (passed a 20/64-in.-hole screen and retained on a 16/64-in.-hole [0.64 $\mathrm{cm}$ in diameter] screen), and (iv) rejected seed (retained on 24/64-in.-hole screen or passed a 16/64-in.-hole screen). The sized fractions (large, medium, and small) obtained from the yield harvested from each plot were weighed; and from these fractions, 200 seeds were selected randomly and weighed. All seeds in a fraction were weighed if there were fewer than 200. The weight per kernel for each fraction was determined by dividing the weight of the sample by the number of seeds in the sample. These data were used to calculate the number of units of salable seed $(80,000$ seeds per unit at $12 \%$ moisture) per acre.

Economic analysis. Data on production and fungicide application costs were obtained by interviewing representatives of various seed corn companies. Because this information is highly confidential, the companies that provided it are not identified. The wholesale price of seed corn for each year was obtained from seed corn brokers and seed companies in Iowa. The average value was truncated to $\$ 30 /$ unit of 80,000 seeds with a bonus of $\$ 2 /$ unit for mediumsized seed and represents the average price of seed corn among seed companies. A premium is usually added to the price of medium-grade seed because this fraction is

Table 5. May futures prices (no. 2 corn) used in economic analysis of fungicide usage in experimental plots in hybrid corn seed production fields in Iowa, 1990 to 1993

\begin{tabular}{lcc}
\hline $\begin{array}{l}\text { Date } \\
\text { of price }\end{array}$ & $\begin{array}{c}\text { Price } \\
\text { (\$/bushel) }\end{array}$ & $\begin{array}{c}\text { Year of } \\
\text { experiment }\end{array}$ \\
\hline $3 / 1 / 91$ & 2.55 & 1990 \\
$3 / 2 / 92$ & 2.76 & 1991 \\
$3 / 1 / 93$ & 2.22 & 1992 \\
$3 / 2 / 94$ & 2.91 & 1993 \\
\hline
\end{tabular}

Table 6. Increased total and medium salable seed units and increased total yield resulting from fungicide treatments in experimental plots in four commercial hybrid corn seed production fields in Iowa, 1993

\begin{tabular}{|c|c|c|c|c|c|c|c|c|c|c|c|c|}
\hline \multirow[b]{2}{*}{ Treatment $^{\mathbf{x}}$} & \multicolumn{3}{|c|}{ Field 93 A, Benton County } & \multicolumn{3}{|c|}{ Field 93 C, Marshall County } & \multicolumn{3}{|c|}{ Field 93 E, Story County } & \multicolumn{3}{|c|}{ Field 93 H, Webster County } \\
\hline & $\begin{array}{c}\text { Increased } \\
\text { total } \\
\text { units } \\
\text { (per acre) }\end{array}$ & $\begin{array}{c}\text { Increased } \\
\text { medium } \\
\text { units } \\
\text { (per acre) }\end{array}$ & $\begin{array}{c}\text { Increased } \\
\text { total } \\
\text { yield } \\
\text { (bu/acre) }\end{array}$ & $\begin{array}{c}\text { Increased } \\
\text { total } \\
\text { units } \\
\text { (per acre) }\end{array}$ & $\begin{array}{c}\text { Increased } \\
\text { medium } \\
\text { units } \\
\text { (per acre) }\end{array}$ & $\begin{array}{c}\text { Increased } \\
\text { total } \\
\text { yield } \\
\text { (bu/acre) }\end{array}$ & $\begin{array}{c}\text { Increased } \\
\text { total } \\
\text { units } \\
\text { (per acre) }\end{array}$ & $\begin{array}{c}\text { Increased } \\
\text { medium } \\
\text { units } \\
\text { (per acre) }\end{array}$ & $\begin{array}{c}\text { Increased } \\
\text { total } \\
\text { yield } \\
\text { (bu/acre) }\end{array}$ & $\begin{array}{c}\text { Increased } \\
\text { total } \\
\text { units } \\
\text { (per acre) }\end{array}$ & $\begin{array}{c}\text { Increased } \\
\text { medium } \\
\text { units } \\
\text { (per acre) }\end{array}$ & $\begin{array}{c}\text { Increased } \\
\text { total } \\
\text { yield } \\
\text { (bu/acre) }\end{array}$ \\
\hline \multicolumn{13}{|l|}{ Chlorothalonil } \\
\hline $1,2,3,4,5^{y}$ & $26.8 \mathrm{a}$ & $3.76 \mathrm{a}$ & $9.72 \mathrm{a}$ & $11.7 \mathrm{a}-\mathrm{c}$ & $1.90 \mathrm{a}-\mathrm{c}$ & $5.30 \mathrm{a}-\mathrm{c}$ & $14.3 \mathrm{a}$ & $8.44 \mathrm{a}$ & $7.86 \mathrm{a}$ & $17.8 \mathrm{ab}$ & $8.70 \mathrm{a}-\mathrm{c}$ & $10.59 \mathrm{ab}$ \\
\hline Propiconazole 1,2 & & & & & & & & & & & & \\
\hline+ mancozeb 3 & $23.1 \mathrm{ab}$ & $2.17 \mathrm{bc}$ & $8.65 \mathrm{ab}$ & $26.0 \mathrm{a}$ & $5.78 \mathrm{a}$ & $11.62 \mathrm{a}$ & $9.4 \mathrm{ab}$ & $5.04 \mathrm{a}-\mathrm{c}$ & $5.36 \mathrm{a}$ & $23.9 \mathrm{a}$ & $11.74 \mathrm{ab}$ & $13.44 \mathrm{a}$ \\
\hline Mancozeb 1,2,3 & $25.8 \mathrm{a}$ & $3.82 \mathrm{a}$ & $8.95 \mathrm{a}$ & $16.1 \mathrm{ab}$ & $3.49 \mathrm{ab}$ & $10.21 \mathrm{a}$ & $11.8 \mathrm{ab}$ & $5.65 \mathrm{ab}$ & $6.98 \mathrm{a}$ & $10.7 \mathrm{~b}-\mathrm{d}$ & $9.51 \mathrm{a}-\mathrm{c}$ & $8.92 \mathrm{a}-\mathrm{c}$ \\
\hline Chlorothalonil 1,2 & $15.0 \mathrm{bc}$ & $2.41 \mathrm{ab}$ & $5.10 \mathrm{c}$ & $9.9 \mathrm{a}-\mathrm{c}$ & $0.86 \mathrm{bc}$ & $5.41 \mathrm{a}-\mathrm{c}$ & $11.3 \mathrm{ab}$ & $6.44 \mathrm{ab}$ & $6.09 \mathrm{a}$ & $14.7 \mathrm{a}-\mathrm{c}$ & $15.18 \mathrm{a}$ & $9.87 \mathrm{ab}$ \\
\hline \multicolumn{13}{|l|}{ Chlorothalonil } \\
\hline $2,3,4$ & $13.3 \mathrm{~cd}$ & $0.83 \mathrm{~cd}$ & $5.11 \mathrm{c}$ & $7.8 \mathrm{bc}$ & $0.33 \mathrm{bc}$ & $5.04 \mathrm{a}-\mathrm{c}$ & $7.6 \mathrm{a}-\mathrm{c}$ & $4.30 \mathrm{a}-\mathrm{c}$ & $4.26 \mathrm{ab}$ & $3.6 \mathrm{~cd}$ & $3.24 \mathrm{~cd}$ & $2.20 \mathrm{~cd}$ \\
\hline Propiconazole 1,2 & $12.2 \mathrm{~cd}$ & $1.17 \mathrm{~b}-\mathrm{d}$ & $3.52 \mathrm{~cd}$ & $14.3 \mathrm{ab}$ & $2.46 \mathrm{a}-\mathrm{c}$ & $7.49 \mathrm{ab}$ & $10.1 \mathrm{ab}$ & $4.21 \mathrm{a}-\mathrm{c}$ & $5.59 \mathrm{a}$ & $7.5 \mathrm{~b}-\mathrm{d}$ & $6.27 \mathrm{bc}$ & $5.61 \mathrm{a}-\mathrm{d}$ \\
\hline Chlorothalonil 2,3 & $14.9 \mathrm{bc}$ & $0.92 \mathrm{~b}-\mathrm{d}$ & $5.14 \mathrm{bc}$ & $5.2 \mathrm{bc}$ & $2.23 \mathrm{a}-\mathrm{c}$ & $2.63 \mathrm{bc}$ & $5.3 \mathrm{bc}$ & $3.43 \mathrm{a}-\mathrm{c}$ & $3.17 \mathrm{ab}$ & $2.9 \mathrm{~cd}$ & $3.95 \mathrm{bc}$ & $3.78 \mathrm{~b}-\mathrm{d}$ \\
\hline Propiconazole 2 & $9.1 \mathrm{~cd}$ & $0.65 \mathrm{~cd}$ & $2.82 \mathrm{~cd}$ & $9.2 \mathrm{bc}$ & $-0.29 \mathrm{c}$ & $5.20 \mathrm{bc}$ & $4.8 \mathrm{bc}$ & $5.02 \mathrm{a}-\mathrm{c}$ & $3.11 \mathrm{ab}$ & $6.1 \mathrm{~b}-\mathrm{d}$ & $6.07 \mathrm{bc}$ & $5.59 \mathrm{a}-\mathrm{d}$ \\
\hline Chlorothalonil 2 & $4.3 \mathrm{de}$ & $0.01 \mathrm{~d}$ & $1.06 \mathrm{~d}$ & $4.7 \mathrm{bc}$ & $0.03 \mathrm{c}$ & $3.93 \mathrm{bc}$ & $7.1 \mathrm{bc}$ & $1.73 \mathrm{bc}$ & $3.48 \mathrm{ab}$ & $4.7 \mathrm{~cd}$ & $7.70 \mathrm{bc}$ & $5.57 \mathrm{a}-\mathrm{d}$ \\
\hline Untreated & $0.0 \mathrm{e}$ & $0.00 \mathrm{~d}$ & $0.00 \mathrm{~d}$ & $0.0 \mathrm{c}$ & $0.00 \mathrm{c}$ & $0.00 \mathrm{c}$ & $0.0 \mathrm{c}$ & $0.00 \mathrm{c}$ & $0.00 \mathrm{~b}$ & $0.0 \mathrm{~d}$ & $0.00 \mathrm{c}$ & $0.00 \mathrm{~d}$ \\
\hline $\mathrm{CV}^{\mathrm{z}}(\%)$ & 43.3 & 66.9 & 49.9 & 95.5 & 158.1 & 79.9 & 75.3 & 86.2 & 76.1 & 98.4 & 72.2 & 70.8 \\
\hline
\end{tabular}

x Treatment means followed by the same letter are not significantly different at $P=0.05$ according to the least significant difference test.

y 1 = first spray, 7 to 13 days before the second spray; 2 = second spray, just before detasseling; $3=$ third spray, just after detasseling; $4=$ fourth spray, 10 to 13 days after the third spray; and 5 = fifth spray, 10 to 11 days after the fourth spray.

${ }^{\mathrm{z}}$ Coefficient of variation. 
associated with higher germination, greater seedling vigor, and better planting than other seed grades. The genotype of the seed causes some variation in price, but all companies and brokers agreed that our truncated values were reasonable estimates. Fungicide prices were obtained from suppliers of the products in Iowa, and the lowest quoted bulk price was used in calculations (Table 4). The wholesale price of seed was used instead of the retail price because the wholesale price did not involve a number of intangibles that the retail prices entailed. These intangibles vary with the contract between the seed company and the farmer purchasing the seed and include factors such as transportation costs, discounts to farmers, and incentives to sales representatives. Fungicide was presumed to be custom applied, and the average quoted cost during the 4 years of our study (for both aerial and ground equipment) was $\$ 5.00 /$ acre $(\$ 12.35 / \mathrm{ha})$.

The inbred (or variety) production factor is a special weighting factor used to express inbred corn yields in commercial corn equivalents as a means to standardize payments (on a per acre basis) to growers producing seed crops (21). There are almost as many contracts as there are seed companies, and some companies may have several different contract options (21). When the inbred production factor is used as a yield criterion, payment to the grower is calculated as the product of the total yield (bushels per acre), the inbred production factor, and some local or national price reference for commercial corn. A common price reference is the May Chicago Board of Trade futures price for no. 2 corn quoted on 1 March of the following year. May futures prices for no. 2 corn were used in this analysis (Table 5).

Economic analysis for each fungicide treatment was based on the method proposed by Bourdot and Saville (3):

$$
R_{\mathrm{n}}=I_{\mathrm{i}}-E_{\mathrm{i}}
$$

in which $R_{\mathrm{n}}=$ net return (\$/acre) to the seed company resulting from fungicide usage; $I_{\mathrm{i}}=$ increased income $(\$ /$ acre) or monetary value of preventable crop loss resulting from fungicide usage; and $E_{\mathrm{i}}=$ increased expenses (\$/acre) or treatment cost (fungicide + application cost). $I_{\mathrm{i}}$ was calculated as

$$
I_{\mathrm{i}}=Y_{\mathrm{u}} P+Y_{\mathrm{m}} K
$$

in which $Y_{\mathrm{u}}=$ increased yield (units/acre) resulting from fungicide usage (includes large, medium, and small seed fractions); $P=$ wholesale price of seed corn (\$30/unit in this study); $Y_{\mathrm{m}}=$ increased medium grade units per acre resulting from fungicide usage; and $K=$ premium on each medium grade unit ( $\$ 2 /$ unit in this study). $E_{\mathrm{i}}$ was calculated as

$$
E_{\mathrm{i}}=f n+a n+q Y_{\mathrm{u}}+Y_{\mathrm{h}} m b
$$

in which $f=$ price of fungicide (\$/application/acre); $n=$ number of fungicide applications; $a=$ fungicide application cost (\$/application/acre); $q=$ cost of processing increased yield resulting from fungicide usage (\$4.16/unit in this study); $Y_{\mathrm{h}}=$ increased harvested yield (bushels/acre) resulting from fungicide usage (includes large, medium, small, and rejected seed fractions); $m=$ May futures price for no. 2 corn on 1 March (\$/bushel); and $b=$ average inbred production factor (1.75 for Iowa).

Payment to the grower (\$/acre) by the seed company for increased yield resulting from fungicide usage is represented by $Y_{\mathrm{h}} m b$. Although this component in the model is an added cost to the seed company, it is increased return to the grower and has value to the seed company because it increases grower satisfaction and the likelihood that the grower will sign future contracts with the company that effectively controls diseases.

The overall economic model is

$$
R_{\mathrm{n}}=\left(Y_{\mathrm{u}} P+Y_{\mathrm{m}} K\right)-\left(f n+a n+q Y_{\mathrm{u}}+Y_{\mathrm{h}} m b\right)
$$

in which the variables are as already defined. The subscripts in the model are defined as follows: $h$ refers to harvested (yield), i refers to increased (income or expenses), $\mathrm{m}$ refers to medium (units), $\mathrm{n}$

\begin{tabular}{|c|c|c|c|}
\hline Treatment $^{x}$ & $\begin{array}{c}\text { Net return } \\
\text { (\$/acre) }\end{array}$ & $\begin{array}{c}\text { Grower pay } \\
\text { (\$/acre) }\end{array}$ & $\begin{array}{c}\text { Gray leaf spot } \\
\text { at GS 8.2 } \\
(\% \text { LAD) }\end{array}$ \\
\hline Untreated & $0.0 \mathrm{a}$ & $0.0 \mathrm{a}$ & $10.4 \mathrm{a}$ \\
\hline Copper thallate $1,2,3^{y}$ & $-17.1 \mathrm{a}$ & $2.0 \mathrm{a}$ & $2.9 \mathrm{~b}$ \\
\hline Propiconazole $1,2+$ chlorothalonil 3 & $-41.7 \mathrm{a}$ & $1.5 \mathrm{a}$ & $0.4 \mathrm{~b}$ \\
\hline \multicolumn{4}{|l|}{ Chlorothalonil 1,2} \\
\hline $2.2 \mathrm{lb}$ a.i./acre & $-83.4 \mathrm{a}$ & $-7.0 \mathrm{a}$ & $0.9 \mathrm{~b}$ \\
\hline $1.5 \mathrm{lb}$ a.i./acre & $-85.2 \mathrm{a}$ & $-8.1 \mathrm{a}$ & $1.0 \mathrm{~b}$ \\
\hline Propiconazole 1,2 & $-86.2 \mathrm{a}$ & $-9.7 \mathrm{a}$ & $1.4 \mathrm{~b}$ \\
\hline Chlorothalonil 2,3 & $-136.1 \mathrm{a}$ & $-17.0 \mathrm{a}$ & $3.4 \mathrm{~b}$ \\
\hline Chlorothalonil $1,2,3$ & $-172.9 \mathrm{a}$ & $-20.6 \mathrm{a}$ & $0.2 \mathrm{~b}$ \\
\hline $\mathrm{CV}^{\mathrm{z}}(\%)$ & -171.7 & -318.7 & 87.7 \\
\hline
\end{tabular}

Table 8. Net returns, grower pay, and percentage of leaf area diseased (\%LAD) resulting from fungicide treatments in experimental plots in commercial hybrid corn seed production field $91 \mathrm{~A}$ in Mahaska County, Iowa, 1991

x Treatment means followed by the same letter are not significantly different at $P=0.05$ according to the least significant difference test.

y 1 = first spray, at growth stage (GS) 4.0; $2=$ second spray, at GS 5.5; and $3=$ third spray, at GS 6.8.

\begin{tabular}{|c|c|c|c|c|c|c|c|c|c|c|c|c|}
\hline \multirow[b]{2}{*}{ Treatment $^{\mathrm{u}}$} & \multicolumn{3}{|c|}{ Field 90 A, Marshall County } & \multicolumn{3}{|c|}{ Field 90 B, Mahaska County } & \multicolumn{3}{|c|}{ Field 90 C, Jefferson County } & \multicolumn{3}{|c|}{ Field 90 D, Henry County } \\
\hline & $\begin{array}{c}\text { Net } \\
\text { return } \\
\text { (\$/acre) }\end{array}$ & $\begin{array}{c}\text { Grower } \\
\text { pay } \\
\text { (\$/acre) }\end{array}$ & $\begin{array}{c}\text { Common } \\
\text { rust } \\
\text { at GS 8.5 } \\
(\% \text { LAD })^{\mathbf{w}}\end{array}$ & $\begin{array}{c}\text { Net } \\
\text { return } \\
\text { (\$/acre) }\end{array}$ & $\begin{array}{c}\text { Grower } \\
\text { pay } \\
\text { (\$/acre) }\end{array}$ & 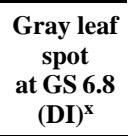 & $\begin{array}{c}\text { Net } \\
\text { return } \\
\text { (\$/acre) }\end{array}$ & $\begin{array}{c}\text { Grower } \\
\text { pay } \\
\text { (\$/acre) }\end{array}$ & $\begin{array}{c}\text { Northern } \\
\text { leaf blight } \\
\text { at GS } 7.2 \\
(\% \text { LAD) }\end{array}$ & $\begin{array}{c}\text { Net } \\
\text { return } \\
\text { (\$/acre) }\end{array}$ & $\begin{array}{c}\text { Grower } \\
\text { pay } \\
\text { (\$/acre) }\end{array}$ & $\begin{array}{c}\text { Northern } \\
\text { leaf blight } \\
\text { at GS } 6.0 \\
\text { (DI) }\end{array}$ \\
\hline Copper thallate $2^{\mathrm{y}}$ & $173.8 \mathrm{a}$ & $24.8 \mathrm{a}$ & $13.8 \mathrm{a}$ & $-68.5 \mathrm{a}$ & $3.4 \mathrm{ab}$ & $4.6 \mathrm{ab}$ & $-88.5 \mathrm{a}$ & $1.2 \mathrm{a}$ & $37.5 \mathrm{a}$ & $-75.6 \mathrm{a}$ & $-3.6 \mathrm{a}$ & $2.5 \mathrm{a}$ \\
\hline Chlorothalonil 2 & $55.0 \mathrm{a}$ & $1.1 \mathrm{a}$ & $18.8 \mathrm{a}$ & $18.1 \mathrm{a}$ & $10.6 \mathrm{ab}$ & $4.3 \mathrm{ab}$ & $-87.9 \mathrm{a}$ & $2.3 \mathrm{a}$ & $24.0 \mathrm{~b}$ & $-87.7 \mathrm{a}$ & $-2.7 \mathrm{a}$ & $2.6 \mathrm{a}$ \\
\hline Propiconazole 2 & $45.5 \mathrm{a}$ & $13.2 \mathrm{a}$ & $16.3 \mathrm{ab}$ & $52.6 \mathrm{a}$ & $13.8 \mathrm{ab}$ & $4.3 \mathrm{ab}$ & $-46.2 \mathrm{a}$ & $7.4 \mathrm{a}$ & $25.0 \mathrm{~b}$ & $9.7 \mathrm{a}$ & $1.6 \mathrm{a}$ & $2.1 \mathrm{a}$ \\
\hline Copper thallate 1,2 & $10.4 \mathrm{a}$ & $3.7 \mathrm{a}$ & $12.0 \mathrm{a}-\mathrm{c}$ & $-69.7 \mathrm{a}$ & $-3.0 \mathrm{~b}$ & $4.0 \mathrm{bc}$ & $-100.5 \mathrm{a}$ & $-1.5 \mathrm{a}$ & $21.8 \mathrm{bc}$ & $-62.8 \mathrm{a}$ & $-4.0 \mathrm{a}$ & $1.9 \mathrm{a}$ \\
\hline Chlorothalonil 1,2 & $4.7 \mathrm{a}$ & $12.3 \mathrm{a}$ & $10.5 \mathrm{bc}$ & $11.1 \mathrm{a}$ & $21.5 \mathrm{a}$ & $3.5 \mathrm{c}$ & $-55.4 \mathrm{a}$ & $22.4 \mathrm{a}$ & $21.3 \mathrm{bc}$ & $-75.9 \mathrm{a}$ & $11.7 \mathrm{a}$ & $2.5 \mathrm{a}$ \\
\hline Propiconazole 1,2 & $-24.7 \mathrm{a}$ & $8.3 \mathrm{a}$ & $6.3 \mathrm{c}$ & $-4.6 \mathrm{a}$ & $15.5 \mathrm{ab}$ & $4.0 \mathrm{bc}$ & $-30.7 \mathrm{a}$ & $-3.7 \mathrm{a}$ & $14.0 \mathrm{c}$ & $-50.0 \mathrm{a}$ & $6.0 \mathrm{a}$ & $2.5 \mathrm{a}$ \\
\hline Untreated & $0.0 \mathrm{a}$ & $0.0 \mathrm{a}$ & $12.8 \mathrm{a}-\mathrm{c}$ & $0.0 \mathrm{a}$ & $0.0 \mathrm{~b}$ & $4.9 \mathrm{a}$ & $0.0 \mathrm{a}$ & $0.0 \mathrm{a}$ & $43.5 \mathrm{a}$ & $0.0 \mathrm{a}$ & $0.0 \mathrm{a}$ & $2.0 \mathrm{a}$ \\
\hline $\mathrm{CV}^{\mathrm{z}}(\%)$ & 391.7 & 232.2 & 40.1 & $-1,109.7$ & 143.0 & 11.7 & -317.4 & 643.3 & 24.9 & -193.4 & $1,007.7$ & 36.5 \\
\hline
\end{tabular}
${ }^{\mathrm{z}}$ Coefficient of variation.

Table 7. Net returns, grower pay, and disease levels resulting from fungicide treatments in experimental plots in commercial hybrid corn seed production fields in Iowa, 1990

u Treatment means followed by the same letter are not significantly different at $P=0.05$ according to the least significant difference test.

${ }^{v}$ GS = growth stage.

${ }^{\mathrm{w}}$ Percentage of leaf area diseased.

${ }^{x}$ Disease injury index (0 to 9 scale)

y 1 = first spray, at GS 5.0 (fields 90 A and B) or GS 6.0 (fields 90 C and D); and $2=$ second spray, at GS 6.0 (fields 90 A and B) or GS 7.0 (fields 90 C and D).

${ }^{\mathrm{z}}$ Coefficient of variation. 
refers to net (return), and u refers to units (large, medium, or small).

An SI version of the model is

$$
R_{\mathrm{n}}=\left(Y_{\mathrm{u}} P+Y_{\mathrm{m}} K\right)-\left(f n+a n+q Y_{\mathrm{u}}+Y_{\mathrm{h}} m b c\right)
$$

where $R_{\mathrm{n}}=$ net return $(\$ / \mathrm{ha})$ to the seed company resulting from fungicide usage; $Y_{\mathrm{u}}=$ increased yield (units/ha) resulting from fungicide usage (includes large, medium, and small seed fractions); $P=$ wholesale price of seed corn (\$30/unit in this study); $Y_{\mathrm{m}}=$ increased medium grade units per hectare resulting from fungicide usage; $K=$ premium on each medium grade unit (\$2/unit in this study); $f=$ price of fungicide (\$/application/ha); $n=$ number of fungicide applications; $a=$ fungicide application cost (\$/application/ha); $q=$ cost of processing increased yield resulting from fungicide usage (\$4.16/unit in this study); $Y_{\mathrm{h}}=$ increased harvested yield $(\mathrm{kg} / \mathrm{ha})$ resulting from fungicide usage (includes large, medium, small, and rejected seed fractions); $m=$ May futures price for no. 2 corn on 1 March (\$/bushel); $b=$ average inbred production factor (1.75 for Iowa); and $c=$ conversion factor for $\$ /$ bushel to $\$ / \mathrm{kg}(0.0394) . Y_{\mathrm{u}} P+Y_{\mathrm{m}} K$ represents increased income $\left(I_{\mathrm{i}}\right)$ or the monetary value of preventable crop loss resulting from fungicide usage; $f n+a n+q Y_{\mathrm{u}}+Y_{\mathrm{h}} m b c$ represents increased expenses $\left(E_{\mathrm{i}}\right)$, or treatment cost (fungicide + application cost); and $Y_{\mathrm{h}} m b c$ represents increased payment to the grower ( $\$ / \mathrm{ha}$ ) by the seed company resulting from fungicide usage. The subscripts are as already defined.

The effect of fungicide application timing on net returns was evaluated by comparing treatments within an experiment that had an equivalent number of chlorothalonil applications but differed only in the timing of sprays. Only chlorothalonil treatments were used for this comparison because chlorothalonil was the main fungicide in our study and was tested on a scale wider than that of other fungicides. Propor- tions of treatments that resulted in positive net returns to the seed company were obtained by dividing the number of treatments that resulted in positive net returns by the total number of treatments for each fungicide, year, or overall duration of study. Proportions of treatments that resulted in positive payments to the grower by the seed company were obtained similarly.

Data analysis. Data were analyzed by the general linear models procedure. The least significant difference test (22) was used to make planned pairwise means comparisons for disease estimates, increased yield, increased net returns to the seed company, and increased payments to the grower (by the seed company) resulting from fungicide usage.

\section{RESULTS}

Increased yield components $\left(Y_{\mathrm{h}}, Y_{\mathrm{m}}\right.$, and $Y_{\mathrm{u}}$ ) from four experiments in 1993 are given in Table 6. These data are presented for readers who may be interested in sub- stituting increased yield data in our model to obtain net returns $\left(R_{\mathrm{n}}\right)$ to the seed company and payments to the grower $\left(Y_{\mathrm{h}} m b\right)$ by the seed company. Values of other required variables can be obtained from appropriate tables and sections of the text. Values of $R_{\mathrm{n}}$ and $Y_{\mathrm{h}} m b$ from these four experiments are presented later in this section.

1990. Moderately wet conditions and mild temperatures before detasseling were followed by dry conditions and moderate temperatures the rest of the growing season (19). Stewart's disease was prevalent in the central, southern, and southeastern parts of the state where our experiments were conducted. Common rust, gray leaf spot, and northern corn leaf blight were the predominant fungal diseases at experimental sites. Net returns to the seed company resulting from fungicide usage ranged from $-\$ 100 /$ acre $(-\$ 247 / \mathrm{ha})$ to $\$ 174 /$ acre $(\$ 430 / \mathrm{ha})$. Payments to the grower by the seed company resulting from fungicide usage ranged from $-\$ 4 /$ acre ( $-\$ 10 /$ ha) to $\$ 25 /$ acre $(\$ 62 /$

Table 10. Net returns, grower pay, and percentage of leaf area diseased (\%LAD) resulting from fungicide treatments in experimental plots in commercial hybrid corn seed production field $92 \mathrm{E}$ in Tama County, Iowa, 1992

\begin{tabular}{|c|c|c|c|}
\hline Treatment $^{\mathrm{x}}$ & $\begin{array}{c}\text { Net } \\
\text { return } \\
\text { (\$/acre) }\end{array}$ & $\begin{array}{c}\text { Grower } \\
\text { pay } \\
\text { (\$/acre) }\end{array}$ & $\begin{array}{l}\text { Northern } \\
\text { leaf spot } \\
\text { at GS 8.5 } \\
\text { (\% LAD) }\end{array}$ \\
\hline Chlorothalonil 1,2 y & $13.4 \mathrm{a}$ & $6.3 \mathrm{a}-\mathrm{c}$ & $8.4 \mathrm{a}-\mathrm{c}$ \\
\hline Mancozeb 1,2,3 & $11.4 \mathrm{a}$ & $13.2 \mathrm{a}$ & $3.7 \mathrm{~d}$ \\
\hline Untreated & $0.0 \mathrm{a}$ & $0.0 \mathrm{~b}-\mathrm{d}$ & $9.3 \mathrm{ab}$ \\
\hline Chlorothalonil 2,3 & $-1.0 \mathrm{ab}$ & $7.8 \mathrm{ab}$ & $5.0 \mathrm{~b}-\mathrm{d}$ \\
\hline Propiconazole $1+$ chlorothalonil 2 & $-7.9 \mathrm{a}-\mathrm{c}$ & $6.2 \mathrm{a}-\mathrm{c}$ & $3.9 \mathrm{~d}$ \\
\hline Chlorothalonil 1 & $-12.5 \mathrm{a}-\mathrm{c}$ & $-4.2 \mathrm{~b}-\mathrm{d}$ & $6.2 \mathrm{a}-\mathrm{d}$ \\
\hline Propiconazole 1 & $-66.5 b-d$ & $-5.8 \mathrm{~cd}$ & $10.0 \mathrm{a}$ \\
\hline Chlorothalonil 1,2,3 & $-67.7 \mathrm{~cd}$ & $1.3 \mathrm{a}-\mathrm{d}$ & $4.5 \mathrm{~cd}$ \\
\hline Propiconazole 1,2 & $-69.2 \mathrm{~cd}$ & $-7.7 \mathrm{~d}$ & $5.2 \mathrm{~b}-\mathrm{d}$ \\
\hline Chlorothalonil 2 & $-79.3 \mathrm{~d}$ & $-7.5 \mathrm{~d}$ & $6.6 \mathrm{a}-\mathrm{d}$ \\
\hline $\mathrm{CV}^{\mathrm{z}}(\%)$ & -167.2 & 883.1 & 48.8 \\
\hline
\end{tabular}

x Treatment means followed by the same letter are not significantly different at $P=0.05$ according to the least significant difference test.

${ }^{\mathrm{y}} 1$ = first spray, at growth stage (GS) 4.0;2 = second spray, at GS 5.5; and 3 = third spray, at GS 7.0. ${ }^{\mathrm{z}}$ Coefficient of variation.

Table 9. Net returns, grower pay, and percentage of leaf area diseased (\%LAD) resulting from fungicide treatments in experimental plots in commercial hybrid corn seed production fields in Iowa, 1992

\begin{tabular}{|c|c|c|c|c|c|c|c|c|c|c|c|c|}
\hline \multirow[b]{2}{*}{ Treatment $^{\mathrm{x}}$} & \multicolumn{3}{|c|}{ Field 92 A, Benton County } & \multicolumn{3}{|c|}{ Field 92 B, Benton County } & \multicolumn{3}{|c|}{ Field 92 C, Marshall County } & \multicolumn{3}{|c|}{ Field 92 D, Grundy County } \\
\hline & $\begin{array}{c}\text { Net } \\
\text { return } \\
(\$ / \text { acre })\end{array}$ & $\begin{array}{c}\text { Grower } \\
\text { pay } \\
\text { (\$/acre) }\end{array}$ & $\begin{array}{c}\text { Common } \\
\text { rust } \\
\text { at GS 8.2 } \\
\text { (\% LAD) }\end{array}$ & $\begin{array}{l}\text { Net } \\
\text { return } \\
\text { (\$/acre) }\end{array}$ & $\begin{array}{c}\text { Grower } \\
\text { pay } \\
\text { (\$/acre) }\end{array}$ & $\begin{array}{c}\text { Common } \\
\text { rust } \\
\text { at GS 8.5 } \\
(\% \text { LAD })\end{array}$ & $\begin{array}{c}\text { Net } \\
\text { return } \\
\text { (\$/acre) }\end{array}$ & $\begin{array}{c}\text { Grower } \\
\text { pay } \\
\text { (\$/acre) }\end{array}$ & $\begin{array}{c}\text { Common } \\
\text { rust } \\
\text { at GS 8.5 } \\
(\% \text { LAD })\end{array}$ & $\begin{array}{c}\text { Net } \\
\text { return } \\
\text { (\$/acre) }\end{array}$ & $\begin{array}{c}\text { Grower } \\
\text { pay } \\
\text { (\$/acre) }\end{array}$ & $\begin{array}{c}\text { Common } \\
\text { rust } \\
\text { at GS 8.5 } \\
(\% \text { LAD })\end{array}$ \\
\hline $\begin{array}{l}\text { Mancozeb 1,2,3,4y } \\
\text { Chlorothalonil }\end{array}$ & $92.1 \mathrm{a}$ & $35.6 \mathrm{a}$ & $0.6 \mathrm{c}$ & 362.9 a & $57.1 \mathrm{a}$ & $0.9 \mathrm{~b}$ & $332.6 \mathrm{a}$ & 68.6 & $0.3 \mathrm{c}$ & 467.9 a & $12.7 \mathrm{ab}$ & $0.5 \mathrm{e}$ \\
\hline $1,2,3,4$ & $42.4 \mathrm{a}$ & $24.5 \mathrm{ab}$ & $2.0 \mathrm{c}$ & $177.6 \mathrm{a}-\mathrm{d}$ & $41.5 \mathrm{ab}$ & $2.8 \mathrm{a}$ & $157.5 \mathrm{~b}$ & $48.7 \mathrm{~b}$ & $1.9 \mathrm{c}$ & $437.9 \mathrm{a}$ & $19.9 \mathrm{a}$ & $2.7 \mathrm{de}$ \\
\hline Chlorotl & $-6.3 \mathrm{a}$ & & $5.3 \mathrm{~b}$ & $149.0 \mathrm{a}-\mathrm{d}$ & $19.8 \mathrm{~b}-\mathrm{d}$ & $3.1 \mathrm{a}$ & $52.4 \mathrm{bc}$ & $26.1 \mathrm{~cd}$ & $5.5 \mathrm{~b}$ & $332.2 \mathrm{ab}$ & $12.8 \mathrm{ab}$ & $4.7 \mathrm{~cd}$ \\
\hline Chlorothalonil 2,3 & $17.4 \mathrm{a}$ & $12.1 \mathrm{bc}$ & $5.1 \mathrm{~b}$ & $246.5 \mathrm{a}-\mathrm{c}$ & $34.3 \mathrm{a}-\mathrm{c}$ & $3.8 \mathrm{a}$ & $144.9 \mathrm{~b}$ & $35.9 \mathrm{bc}$ & $2.1 \mathrm{c}$ & $264.3 \mathrm{bc}$ & $14.0 \mathrm{ab}$ & $3.0 \mathrm{de}$ \\
\hline Chlorothalonil 3 & $58.1 \mathrm{a}$ & 13.4 bc & $6.7 \mathrm{~b}$ & $92.5 \mathrm{~b}-\mathrm{d}$ & $19.0 \mathrm{~b}-\mathrm{d}$ & $3.0 \mathrm{a}$ & $-26.0 \mathrm{c}$ & $9.6 \mathrm{ef}$ & $6.0 \mathrm{~b}$ & $75.9 \mathrm{de}$ & $4.4 \mathrm{ab}$ & $10.0 \mathrm{ab}$ \\
\hline Chloro & $-5.3 \mathrm{a}$ & $2.7 \mathrm{c}$ & $6.7 \mathrm{~b}$ & $194.4 \mathrm{a}-\mathrm{d}$ & $33.7 \mathrm{a}-\mathrm{c}$ & $4.1 \mathrm{a}$ & $40.4 \mathrm{bc}$ & $20.9 \mathrm{c}-\mathrm{e}$ & $5.3 \mathrm{~b}$ & $117.8 \mathrm{c}-\mathrm{e}$ & $7.4 \mathrm{ab}$ & $7.2 \mathrm{bc}$ \\
\hline Chlorothalonil 2 & $75.9 \mathrm{a}$ & $15.3 \mathrm{bc}$ & $5.2 \mathrm{~b}$ & $34.3 \mathrm{~cd}$ & $7.3 \mathrm{~cd}$ & $3.8 \mathrm{a}$ & $147.7 \mathrm{~b}$ & $27.5 \mathrm{c}$ & $5.7 \mathrm{~b}$ & $211.6 \mathrm{~b}-\mathrm{d}$ & $9.1 \mathrm{ab}$ & $4.6 \mathrm{~cd}$ \\
\hline Propiconazole 1,2 & $-12.8 \mathrm{a}$ & $5.7 \mathrm{c}$ & $6.6 \mathrm{~b}$ & $28.3 \mathrm{~cd}$ & $15.8 \mathrm{~b}-\mathrm{d}$ & $3.9 \mathrm{a}$ & $84.6 \mathrm{bc}$ & $26.4 \mathrm{~cd}$ & $6.4 \mathrm{~b}$ & $195.4 \mathrm{~b}-\mathrm{d}$ & $12.4 \mathrm{ab}$ & $6.2 \mathrm{c}$ \\
\hline Propiconazole 2 & $41.1 \mathrm{a}$ & $14.7 \mathrm{bc}$ & $7.0 \mathrm{~b}$ & $287.3 \mathrm{ab}$ & $37.4 \mathrm{ab}$ & $3.4 \mathrm{a}$ & $-15.5 \mathrm{c}$ & $11.1 \mathrm{~d}-\mathrm{f}$ & $7.7 \mathrm{~b}$ & $173.3 \mathrm{~cd}$ & $11.7 \mathrm{ab}$ & $6.6 \mathrm{c}$ \\
\hline Untreated & $0.0 \mathrm{a}$ & $0.0 \mathrm{c}$ & $9.7 \mathrm{a}$ & $0.0 \mathrm{~d}$ & $0.0 \mathrm{~d}$ & $3.4 \mathrm{a}$ & $0.0 \mathrm{c}$ & $0.0 \mathrm{f}$ & $12.4 \mathrm{a}$ & $0.0 \mathrm{e}$ & $0.0 \mathrm{~b}$ & $11.6 \mathrm{a}$ \\
\hline $\mathrm{CV}^{\mathrm{z}}(\%)$ & 276.1 & 92.9 & 24.9 & 104.8 & 76.7 & 29.2 & 105.4 & 40.8 & 38.3 & 46.2 & 106.3 & 37.4 \\
\hline
\end{tabular}

$\times$ Treatment means followed by the same letter are not significantly different at $P=0.05$ according to the least significant difference test.

y 1 = first spray, at growth stage (GS) $2.5 ; 2=$ second spray, at GS 4.0; 3 = third spray, at GS 5.5; 4 = fourth spray, at GS 7.0.

${ }^{\mathrm{z}}$ Coefficient of variation. 
ha). Differences in net returns to the seed company and to the grower among fungicide treatments were not significant $(P=$ $0.05)$, despite some significant treatment differences $(P \leq 0.05)$ in disease levels between one fungicide application and two fungicide applications (Table 7).
1991. Very dry conditions prevailed during most of the growing season (19), and consequently disease development was limited. Only gray leaf spot developed at two experimental sites, but the level of development was not agronomically significant. Disease data from one experiment that was harvested and analyzed for net returns are given in Table 8. All fungicide treatments in this experiment resulted in negative net returns to the seed company, ranging from $-\$ 17 /$ acre $(-\$ 42 /$ ha) to $-\$ 173 /$ acre (-\$427/ha) (Table 8). Returns to the grower resulting from fungicide

Table 11. Net returns, grower pay, and standardized area under the disease progress curve (AUDPC) resulting from fungicide treatments in experimental plots in commercial hybrid corn seed production fields in Iowa, 1993

\begin{tabular}{|c|c|c|c|c|c|c|c|c|c|c|c|c|}
\hline \multirow[b]{2}{*}{ Treatment $^{x}$} & \multicolumn{3}{|c|}{ Field 93 A, Benton County } & \multicolumn{3}{|c|}{ Field 93 B, Benton County } & \multicolumn{3}{|c|}{ Field 93 C, Marshall County } & \multicolumn{3}{|c|}{ Field 93 D, Grundy County } \\
\hline & $\begin{array}{c}\text { Net } \\
\text { return } \\
\text { (\$/acre) }\end{array}$ & $\begin{array}{c}\text { Grower } \\
\text { pay } \\
\text { (\$/acre) }\end{array}$ & $\begin{array}{c}\text { Standard- } \\
\text { ized } \\
\text { AUDPC }\end{array}$ & $\begin{array}{c}\text { Net } \\
\text { return } \\
\text { (\$/acre) }\end{array}$ & $\begin{array}{c}\text { Grower } \\
\text { pay } \\
\text { (\$/acre) }\end{array}$ & $\begin{array}{c}\text { Standard- } \\
\text { ized } \\
\text { AUDPC }\end{array}$ & $\begin{array}{c}\text { Net } \\
\text { return } \\
\text { (\$/acre) }\end{array}$ & $\begin{array}{c}\text { Grower } \\
\text { pay } \\
\text { (\$/acre) }\end{array}$ & $\begin{array}{c}\text { Standard- } \\
\text { ized } \\
\text { AUDPC }\end{array}$ & $\begin{array}{c}\text { Net } \\
\text { return } \\
\text { (\$/acre) }\end{array}$ & $\begin{array}{c}\text { Grower } \\
\text { pay } \\
\text { (\$/acre) }\end{array}$ & $\begin{array}{l}\text { Standard- } \\
\text { ized } \\
\text { AUDPC }\end{array}$ \\
\hline \multicolumn{13}{|l|}{ Chlorothalonil } \\
\hline $1,2,3,4,5^{\mathrm{y}}$ & $560.4 \mathrm{a}$ & $49.9 \mathrm{a}$ & $46.0 \mathrm{e}$ & $883.6 \mathrm{a}$ & $68.1 \mathrm{a}$ & $36.7 \mathrm{~d}$ & $189.3 \mathrm{bc}$ & $27.0 \mathrm{a}-\mathrm{c}$ & $27.0 \mathrm{e}$ & $146.3 \mathrm{a}-\mathrm{c}$ & $18.4 \mathrm{ab}$ & $16.8 \mathrm{e}$ \\
\hline \multicolumn{13}{|l|}{ Propiconazole 1,2} \\
\hline+ mancozeb 3 & $518.2 \mathrm{ab}$ & $44.1 \mathrm{ab}$ & $46.9 \mathrm{de}$ & $415.0 \mathrm{~b}$ & $41.4 \mathrm{a}-\mathrm{c}$ & $48.2 \mathrm{c}$ & $585.3 \mathrm{a}$ & $59.2 \mathrm{a}$ & $23.2 \mathrm{f}$ & $217.0 \mathrm{a}$ & $19.9 \mathrm{a}$ & $21.9 \mathrm{~d}$ \\
\hline Mancozeb 1,2,3 & $601.6 \mathrm{a}$ & $45.6 \mathrm{a}$ & $47.1 \mathrm{de}$ & $491.7 \mathrm{~b}$ & $46.1 \mathrm{ab}$ & $51.8 \mathrm{c}$ & $343.8 \mathrm{ab}$ & $52.0 \mathrm{a}$ & $29.6 \mathrm{de}$ & $199.4 \mathrm{ab}$ & $17.5 \mathrm{ab}$ & $14.1 \mathrm{e}$ \\
\hline Chlorothalonil 1,2 & $329.6 \mathrm{bc}$ & $26.0 \mathrm{c}$ & $52.7 \mathrm{c}-\mathrm{e}$ & $474.8 \mathrm{~b}$ & $49.3 \mathrm{a}$ & $48.7 \mathrm{c}$ & $194.2 \mathrm{bc}$ & $27.6 \mathrm{a}-\mathrm{c}$ & $32.7 \mathrm{~cd}$ & $67.5 \mathrm{~cd}$ & $4.7 \mathrm{c}$ & $21.6 \mathrm{~d}$ \\
\hline Chlorothalonil 2,3,4 & $263.8 \mathrm{dc}$ & $26.0 \mathrm{c}$ & $53.8 \mathrm{~cd}$ & $457.8 \mathrm{~b}$ & $48.8 \mathrm{ab}$ & $51.1 \mathrm{c}$ & $122.6 \mathrm{bc}$ & $25.7 \mathrm{a}-\mathrm{c}$ & $35.9 \mathrm{~b}$ & $76.9 \mathrm{~b}-\mathrm{d}$ & $9.2 \mathrm{bc}$ & 29.4 bc \\
\hline Propiconazole 1,2 & $271.7 \mathrm{~cd}$ & $17.9 \mathrm{~cd}$ & $56.8 \mathrm{bc}$ & $384.2 \mathrm{~b}$ & $41.2 \mathrm{a}-\mathrm{c}$ & $53.7 \mathrm{c}$ & $307.1 \mathrm{a}-\mathrm{c}$ & $38.2 \mathrm{ab}$ & $26.7 \mathrm{e}$ & $84.2 \mathrm{~b}-\mathrm{d}$ & $8.8 \mathrm{bc}$ & $25.7 \mathrm{~cd}$ \\
\hline Chlorothalonil 2,3 & $323.8 \mathrm{bc}$ & $26.2 \mathrm{c}$ & $59.0 \mathrm{bc}$ & $429.2 \mathrm{~b}$ & $44.0 \mathrm{a}-\mathrm{c}$ & $52.2 \mathrm{c}$ & $90.3 \mathrm{bc}$ & $13.4 \mathrm{bc}$ & $35.5 \mathrm{bc}$ & $21.5 \mathrm{c}$ & $3.6 \mathrm{c}$ & $31.8 \mathrm{~b}$ \\
\hline Propiconazole 2 & $207.7 \mathrm{c}-\mathrm{e}$ & $14.4 \mathrm{~cd}$ & $57.5 \mathrm{bc}$ & $229.2 \mathrm{bc}$ & $22.1 \mathrm{~b}-\mathrm{d}$ & $53.8 \mathrm{c}$ & $194.7 \mathrm{bc}$ & $26.5 \mathrm{a}-\mathrm{c}$ & $36.5 \mathrm{~b}$ & $89.0 \mathrm{~b}-\mathrm{d}$ & $8.9 \mathrm{bc}$ & $30.8 \mathrm{~b}$ \\
\hline Chlorothalonil 2 & $86.3 \mathrm{de}$ & $5.4 \mathrm{~d}$ & $62.4 \mathrm{ab}$ & $204.3 \mathrm{bc}$ & $17.3 \mathrm{~cd}$ & $60.6 \mathrm{~b}$ & 81.9 bc & $20.0 \mathrm{bc}$ & $36.5 \mathrm{~b}$ & $95.7 b-d$ & $10.2 \mathrm{a}-\mathrm{c}$ & $31.4 \mathrm{~b}$ \\
\hline Untreated & $0.0 \mathrm{e}$ & $0.0 \mathrm{~d}$ & $67.1 \mathrm{a}$ & $0.0 \mathrm{c}$ & $0.0 \mathrm{~d}$ & $71.1 \mathrm{a}$ & $0.0 \mathrm{c}$ & $0.0 \mathrm{c}$ & $42.7 \mathrm{a}$ & $0.0 \mathrm{~d}$ & $0.0 \mathrm{c}$ & $45.0 \mathrm{a}$ \\
\hline \multirow[t]{2}{*}{$\mathrm{CV}^{\mathrm{Z}}(\%)$} & 48.1 & 49.9 & 9.7 & 61.8 & 49.2 & 7.6 & 112.9 & 79.9 & 6.9 & 86.4 & 69.6 & 10.3 \\
\hline & \multicolumn{3}{|c|}{ Field 93 E, Story County } & \multicolumn{3}{|c|}{ Field 93 F, Story County } & \multicolumn{3}{|c|}{ Field 93 G, Webster County } & \multicolumn{3}{|c|}{ Field 93 H, Webster County } \\
\hline $\begin{array}{c}\text { Chlorothalonil } \\
1,2,3,4,5\end{array}$ & 256.6 a & $40.1 \mathrm{a}$ & $9.5 \mathrm{e}$ & $315.9 \mathrm{a}$ & $35.7 \mathrm{a}$ & $12.7 \mathrm{~d}$ & $8.9 \mathrm{bc}$ & $26.9 \mathrm{ab}$ & $12.1 \mathrm{~b}-\mathrm{d}$ & $333.1 \mathrm{ab}$ & $53.9 \mathrm{ab}$ & $13.0 \mathrm{~d}$ \\
\hline \multicolumn{13}{|l|}{ Propiconazole 1,2} \\
\hline+ mancozeb 3 & $186.5 \mathrm{ab}$ & $27.3 \mathrm{ab}$ & $11.2 \mathrm{de}$ & $226.4 \mathrm{ab}$ & $18.5 \mathrm{ab}$ & $11.9 \mathrm{~d}$ & $154.7 \mathrm{a}-\mathrm{c}$ & $29.0 \mathrm{ab}$ & $11.0 \mathrm{~cd}$ & $533.9 \mathrm{a}$ & $68.5 \mathrm{a}$ & $12.8 \mathrm{~d}$ \\
\hline Mancozeb 1,2,3 & $252.7 \mathrm{a}$ & $35.5 \mathrm{ab}$ & $9.8 \mathrm{e}$ & $268.1 \mathrm{ab}$ & $24.7 \mathrm{ab}$ & $12.9 \mathrm{~d}$ & $72.3 \mathrm{a}-\mathrm{c}$ & $27.0 \mathrm{ab}$ & $9.9 \mathrm{~d}$ & $223.6 \mathrm{bc}$ & $45.4 \mathrm{a}-\mathrm{c}$ & $12.7 \mathrm{~d}$ \\
\hline Chlorothalonil 1,2 & $236.9 \mathrm{a}$ & $31.0 \mathrm{ab}$ & $11.3 \mathrm{de}$ & $372.8 \mathrm{a}$ & $30.8 \mathrm{ab}$ & $12.3 \mathrm{~d}$ & $104.6 \mathrm{a}-\mathrm{c}$ & $27.4 \mathrm{ab}$ & $11.9 \mathrm{~b}-\mathrm{d}$ & $323.0 \mathrm{ab}$ & $50.3 \mathrm{ab}$ & $14.3 \mathrm{~cd}$ \\
\hline Chlorothalonil 2,3,4 & $128.9 \mathrm{ab}$ & $21.7 \mathrm{ab}$ & $14.6 \mathrm{bc}$ & $165.6 \mathrm{ab}$ & $19.3 \mathrm{ab}$ & $16.4 \mathrm{bc}$ & $168.4 \mathrm{a}-\mathrm{c}$ & $31.0 \mathrm{ab}$ & $12.8 \mathrm{a}-\mathrm{d}$ & $35.1 \mathrm{c}$ & $11.2 \mathrm{~cd}$ & $13.9 \mathrm{~cd}$ \\
\hline Propiconazole 1,2 & $211.8 \mathrm{ab}$ & $28.5 \mathrm{a}$ & $13.0 \mathrm{~cd}$ & $226.4 \mathrm{ab}$ & $16.4 \mathrm{ab}$ & $14.5 \mathrm{~cd}$ & $291.1 \mathrm{a}$ & $44.8 \mathrm{a}$ & $13.3 \mathrm{a}-\mathrm{c}$ & $148.4 \mathrm{bc}$ & $28.6 \mathrm{a}-\mathrm{d}$ & $13.7 \mathrm{~d}$ \\
\hline Chlorothalonil 2,3 & $91.0 \mathrm{ab}$ & $16.2 \mathrm{ab}$ & $15.2 \mathrm{bc}$ & $199.0 \mathrm{ab}$ & $11.1 \mathrm{ab}$ & $16.4 \mathrm{bc}$ & $60.6 \mathrm{a}-\mathrm{c}$ & $23.2 \mathrm{ab}$ & $14.1 \mathrm{ab}$ & $28.3 \mathrm{c}$ & $19.2 \mathrm{~b}-\mathrm{d}$ & $16.0 \mathrm{bc}$ \\
\hline Propiconazole 2 & $103.3 \mathrm{ab}$ & $15.8 \mathrm{ab}$ & $16.4 \mathrm{~b}$ & $219.1 \mathrm{ab}$ & $15.8 \mathrm{ab}$ & $15.7 \mathrm{bc}$ & $139.9 \mathrm{a}-\mathrm{c}$ & $23.9 \mathrm{ab}$ & $12.7 \mathrm{a}-\mathrm{c}$ & $126.0 \mathrm{bc}$ & $28.5 \mathrm{~b}-\mathrm{d}$ & $17.0 \mathrm{ab}$ \\
\hline Chlorothalonil 2 & $150.6 \mathrm{ab}$ & $17.7 \mathrm{ab}$ & $16.4 \mathrm{~b}$ & $226.2 \mathrm{ab}$ & $12.4 \mathrm{ab}$ & $18.3 \mathrm{ab}$ & $239.2 \mathrm{ab}$ & $35.9 \mathrm{a}$ & $14.1 \mathrm{ab}$ & $89.2 \mathrm{bc}$ & $28.4 \mathrm{a}-\mathrm{d}$ & $15.3 \mathrm{~b}-\mathrm{d}$ \\
\hline Untreated & $0.0 \mathrm{~b}$ & $0.0 \mathrm{~b}$ & $21.3 \mathrm{a}$ & $0.0 \mathrm{~b}$ & $0.0 \mathrm{~b}$ & $20.4 \mathrm{a}$ & $0.0 \mathrm{c}$ & $0.0 \mathrm{~b}$ & $15.1 \mathrm{a}$ & $0.0 \mathrm{c}$ & $0.0 \mathrm{~d}$ & $19.5 \mathrm{a}$ \\
\hline $\mathrm{CV}(\%)$ & 89.7 & 76.1 & 14.4 & 89.8 & 124.1 & 12.7 & 131.2 & 80.6 & 11.7 & 99.1 & 70.8 & 10.5 \\
\hline
\end{tabular}

x Treatment means followed by the same letter are not significantly different at $P=0.05$ according to the least significant difference test.

y 1 = first spray, 7 to 13 days before second spray; $2=$ second spray, just before detasseling; $3=$ third spray, just after detasseling; $4=$ fourth spray, 10 to 13 days after spray 3 ; and $5=$ fifth spray, 10 to 11 days after spray 4 .

${ }^{\mathrm{z}}$ Coefficient of variation.

Table 12. Fungicide treatments applied to experimental plots in commercial hybrid corn seed production fields in Iowa, 1990 to 1993 , and proportions of treatments resulting in positive net returns, $P\left(R_{\mathrm{n}}>0\right)$, and positive grower pay, $P\left(G_{\mathrm{p}}>0\right)$

\begin{tabular}{|c|c|c|c|c|c|c|c|c|c|c|c|}
\hline \multirow{2}{*}{$\begin{array}{l}\text { Fungicide } \\
\text { Number of applications }\end{array}$} & \multicolumn{9}{|c|}{ Number of treatments } & \multirow[b]{2}{*}{$P\left(R_{\mathrm{n}}>\mathbf{0}\right)$} & \multirow[b]{2}{*}{$P\left(G_{\mathrm{p}}>0\right)$} \\
\hline & 1990 & 1991 & 1992 & 1993 & Total & $R_{\mathrm{n}}>\mathbf{0}$ & $R_{\mathrm{n}}<0$ & $G_{\mathrm{p}}>\mathbf{0}$ & $G_{\mathrm{p}}<0$ & & \\
\hline \multicolumn{12}{|l|}{ Chlorothalonil } \\
\hline 1 & 4 & 0 & 10 & 8 & 22 & 16 & 6 & 19 & 3 & 0.73 & 0.86 \\
\hline 2 & 4 & 12 & 14 & 16 & 46 & 27 & 19 & 34 & 12 & 0.59 & 0.74 \\
\hline 3 & 0 & 4 & 1 & 8 & 13 & 8 & 5 & 9 & 4 & 0.62 & 0.69 \\
\hline 4 & 0 & 0 & 4 & 0 & 4 & 3 & 1 & 4 & 0 & 0.75 & 1.00 \\
\hline 5 & 0 & 0 & 0 & 8 & 8 & 8 & 0 & 8 & 0 & 1.00 & 1.00 \\
\hline \multicolumn{12}{|l|}{ Mancozeb } \\
\hline 3 & 0 & 0 & 1 & 8 & 9 & 9 & 0 & 9 & 0 & 1.00 & 1.00 \\
\hline 4 & 0 & 0 & 4 & 0 & 4 & 4 & 0 & 4 & 0 & 1.00 & 1.00 \\
\hline \multicolumn{12}{|l|}{ Propiconazole + mancozeb } \\
\hline $2+1$ & 0 & 0 & 0 & 8 & 8 & 8 & 0 & 8 & 0 & 1.00 & 1.00 \\
\hline \multicolumn{12}{|l|}{ Propiconazole } \\
\hline 1 & 4 & 0 & 5 & 8 & 17 & 14 & 3 & 16 & 1 & 0.82 & 0.94 \\
\hline 2 & 4 & 4 & 5 & 8 & 21 & 10 & 11 & 15 & 6 & 0.48 & 0.71 \\
\hline \multicolumn{12}{|l|}{ Propiconazole + chlorothalonil } \\
\hline $2+1$ & 0 & 4 & 0 & 0 & 4 & 0 & 4 & 1 & 3 & 0.00 & 0.25 \\
\hline $1+1$ & 0 & 0 & 1 & 0 & 1 & 0 & 1 & 1 & 0 & 0.00 & 1.00 \\
\hline \multicolumn{12}{|l|}{ Copper thallate } \\
\hline 1 & 4 & 0 & 0 & 0 & 4 & 1 & 3 & 3 & 1 & 0.25 & 0.75 \\
\hline 2 & 4 & 0 & 0 & 0 & 4 & 1 & 3 & 1 & 3 & 0.25 & 0.25 \\
\hline 3 & 0 & 4 & 0 & 0 & 4 & 0 & 4 & 1 & 3 & 0.00 & 0.25 \\
\hline All treatments & 24 & 28 & 45 & 72 & 169 & 109 & 60 & 133 & 36 & 0.64 & 0.79 \\
\hline
\end{tabular}


usage ranged from $-\$ 21 /$ acre $(-\$ 52 /$ ha) to $\$ 2 /$ acre (\$5/ha). Three of four experiments were not harvested because of water stress damage caused by the dry weather.

1992. During May and June, moderately dry conditions and moderate temperatures prevailed, followed by wet, cool weather during the reproductive phase of the seed corn crop (19). The predominant diseases were common rust and northern leaf spot. Net profits to the seed company of up to $\$ 468 /$ acre $(\$ 1,156 /$ ha) were realized from fungicide usage (Tables 9 and 10). Losses incurred by the seed company ranged from $\$ 1 /$ acre (\$2.50/ha) to $\$ 79 /$ acre (\$195/ha). All fungicide treatments at four of five experimental sites resulted in positive grower pay, ranging from $\$ 4 /$ acre $(\$ 10 /$ ha) to $\$ 69 /$ acre $(\$ 170 /$ ha). At the fifth experimental site, four treatments resulted in negative grower pay, ranging from $\$ 4 /$ acre $(\$ 10 / \mathrm{ha})$ to $\$ 8 /$ acre $(\$ 20 / \mathrm{ha})$. There were significant differences $(P \leq 0.05)$ in net returns and grower pay among treatments: four applications of mancozeb and four applications of chlorothalonil resulted in consistently high returns at four sites. In general, there was an inverse relationship between net returns and disease levels.

1993. Very wet, cool weather prevailed during most of the growing season (13). These conditions favored development of common rust, the predominant disease in all eight experiments. All experiments were harvested and analyzed for economic profit. All fungicide treatments at all experi- mental sites resulted in positive net returns to the seed company and increased pay to the grower by the seed company. Net returns to the seed company were between \$9/acre (\$22/ha) and \$884/acre (\$2,184/ha) (Table 11). Grower pay resulting from fungicide usage ranged from $\$ 4 /$ acre $(\$ 10 /$ ha) to $\$ 69 /$ acre ( $\$ 170 /$ ha). In total, 72 fungicide treatments were applied and $100 \%$ were profitable. Net returns and standardized AUDPC values were inversely related at all experimental sites. The best treatments in terms of net returns were five chlorothalonil applications initiated on the first spray date, three mancozeb applications initiated on the first spray date, and two propiconazole applications initiated on the first spray date followed by one mancozeb application on the third spray date.

Of the 169 fungicide treatments applied to experimental plots in commercial hybrid corn seed production fields in Iowa during the 4-year period of our study, 109 (64\%) resulted in positive net returns to the seed company and $133(79 \%)$ resulted in increased pay to the grower by the seed company (Table 12). Proportions of fungicide treatments that resulted in positive returns to the seed company and to the grower on a year-to-year basis are presented in Table 13.

\section{DISCUSSION}

Economic analyses of fungicide usage in hybrid corn seed production for the 4-year duration of this study have revealed that

Table 13. Number of fungicide treatments resulting in positive and negative net returns, $R_{\mathrm{n}}>0$ and $R_{\mathrm{n}}<0$, respectively; positive and negative grower pay, $G_{\mathrm{p}}>0$ and $G_{\mathrm{p}}<0$, respectively; and proportions of treatments resulting in positive net returns and positive grower pay, $P\left(R_{\mathrm{n}}>0\right)$ and $P\left(G_{\mathrm{p}}>0\right)$, respectively, from experimental plots in commercial hybrid corn seed production fields in Iowa, 1990 to 1993

\begin{tabular}{lccccccc}
\hline Year & Total & $\boldsymbol{R}_{\mathbf{n}}>\mathbf{0}$ & $\boldsymbol{R}_{\mathbf{n}}<\mathbf{0}$ & $\boldsymbol{G}_{\mathbf{p}}>\mathbf{0}$ & $\boldsymbol{G}_{\mathbf{p}}<\mathbf{0}$ & $\boldsymbol{P}\left(\boldsymbol{R}_{\mathbf{n}}>\mathbf{0}\right)$ & $\boldsymbol{P}\left(\boldsymbol{G}_{\mathbf{p}}>\mathbf{0}\right)$ \\
\hline 1990 & 24 & 9 & 15 & 18 & 6 & 0.38 & 0.75 \\
1991 & 28 & 0 & 28 & 2 & 26 & 0.00 & 0.07 \\
1992 & 45 & 28 & 17 & 41 & 4 & 0.62 & 0.91 \\
1993 & 72 & 72 & 0 & 72 & 0 & 1.00 & 1.00 \\
All years & 169 & 109 & 60 & 133 & 36 & 0.64 & 0.79 \\
\hline
\end{tabular}

profitable economic returns can result from applying fungicides for the control of foliar diseases. Net returns varied from year to year because of a number of factors, including (i) variation in climatic conditions and therefore in levels of disease, and (ii) planting of different inbreds each year (susceptibility-resistance effect). Net returns varied by geographical location during the same growing season. For most locations and years, differences in disease levels and net returns were obtained in response to different fungicide treatments.

In maximizing net returns, both the timing and the number of fungicide applications during the growing season are important considerations. Ward et al. (24) found that use of fungicides to control gray leaf spot in maize was most effective in controlling disease and preventing yield loss when sprays were initiated at disease severity levels of 2 to $3 \%$ and continued until physiological maturity. In their study, the number and frequency of fungicide sprays varied with the growth stage at which disease first appeared (early infections required more fungicide sprays). In our study, the greatest net returns resulted from treatments in which fungicide sprays were initiated soon after disease detection and continued for at least three consecutive application dates. Although net returns from fungicide treatments initiated on the first, second, or third application date were mostly not significantly different $(P=$ 0.05 ) (Table 14), the majority of fungicide treatments initiated on earlier dates resulted in greater net returns than those initiated on later application dates. Fungicide treatments initiated before or soon after disease detection are likely to result in greater net returns if weather conditions during the growing season are favorable to the development of damaging levels of disease. Losses are likely to result if fungicides are applied in the absence of disease, when disease levels do not exceed damage thresholds, or when phytotoxicity from fungicide usage occurs. Hence, the

Table 14. Effect of fungicide application timing on net returns (\$/acre) to the seed company in experimental plots in commercial hybrid corn seed production fields in Iowa, 1991 to 1993

\begin{tabular}{|c|c|c|c|c|c|c|c|c|c|c|c|c|c|}
\hline \multirow{2}{*}{$\begin{array}{l}\text { Year } \\
\text { Treatment }\end{array}$} & \multicolumn{13}{|c|}{ Field } \\
\hline & $91 \mathrm{~A}$ & 92 A & $92 \mathrm{~B}$ & $92 \mathrm{C}$ & $92 \mathrm{D}$ & $93 \mathrm{~A}$ & $93 \mathrm{~B}$ & $93 \mathrm{C}$ & $93 \mathrm{D}$ & $93 \mathrm{E}$ & $93 \mathrm{~F}$ & $93 \mathrm{G}$ & $93 \mathrm{H}$ \\
\hline 1991 & & $\ldots$ & $\ldots$ & $\ldots$ & $\ldots$ & $\ldots$ & $\ldots$ & $\ldots$ & $\ldots$ & $\ldots$ & $\ldots$ & $\ldots$ & $\ldots$ \\
\hline Chlorothalonil $1,2^{\mathrm{z}}$ & $-83.4 \mathrm{a}$ & $\ldots$ & $\ldots$ & $\ldots$ & $\ldots$ & $\ldots$ & $\ldots$ & $\ldots$ & $\ldots$ & $\ldots$ & $\ldots$ & $\ldots$ & $\ldots$ \\
\hline Chlorothalonil 2,3 & $-136.1 \mathrm{a}$ & $\ldots$ & $\ldots$ & $\ldots$ & $\ldots$ & $\ldots$ & $\ldots$ & $\ldots$ & $\ldots$ & $\ldots$ & $\ldots$ & $\ldots$ & $\ldots$ \\
\hline 1992 & & & & & & & & & & & & & \\
\hline Chlorothalonil 2,3 & $\ldots$ & $17.4 \mathrm{a}$ & $246.5 \mathrm{a}$ & $144.9 \mathrm{a}$ & $264.3 \mathrm{a}$ & $\ldots$ & $\ldots$ & $\ldots$ & $\ldots$ & $\ldots$ & $\ldots$ & $\ldots$ & $\ldots$ \\
\hline Chlorothalonil 3,4 & $\ldots$ & $-5.3 \mathrm{a}$ & $194.4 \mathrm{a}$ & $40.4 \mathrm{a}$ & $117.8 \mathrm{a}$ & $\ldots$ & $\ldots$ & $\ldots$ & $\ldots$ & $\ldots$ & . . & $\ldots$ & $\ldots$ \\
\hline Chlorothalonil 2 & $\ldots$ & $75.9 \mathrm{a}$ & $34.3 \mathrm{a}$ & $147.7 \mathrm{a}$ & $211.6 \mathrm{a}$ & $\ldots$ & $\ldots$ & $\ldots$ & $\ldots$ & $\ldots$ & $\ldots$ & $\ldots$ & $\ldots$ \\
\hline Chlorothalonil 3 & $\ldots$ & $58.1 \mathrm{a}$ & $92.5 \mathrm{a}$ & $-26.0 \mathrm{~b}$ & $75.9 \mathrm{a}$ & $\ldots$ & $\ldots$ & $\ldots$ & $\ldots$ & $\ldots$ & $\ldots$ & $\ldots$ & $\ldots$ \\
\hline 1993 & & $\cdots$ & $\cdots$ & $\ldots$ & $\cdots$ & & & & & & & & \\
\hline Chlorothalonil 1,2 & $\ldots$ & $\ldots$ & $\ldots$ & $\ldots$ & $\ldots$ & $329.6 \mathrm{a}$ & $474.8 \mathrm{a}$ & $194.2 \mathrm{a}$ & $67.5 \mathrm{a}$ & $236.9 \mathrm{a}$ & $372.8 \mathrm{a}$ & $104.6 \mathrm{a}$ & $323.0 \mathrm{a}$ \\
\hline Chlorothalonil 2,3 & $\ldots$ & $\ldots$ & $\ldots$ & $\ldots$ & $\ldots$ & $323.8 \mathrm{a}$ & $429.2 \mathrm{a}$ & $90.3 \mathrm{a}$ & $21.5 \mathrm{a}$ & $91.0 \mathrm{a}$ & $199.0 \mathrm{a}$ & $60.6 \mathrm{a}$ & $28.3 \mathrm{~b}$ \\
\hline
\end{tabular}

y Treatment means followed by the same letter are not significantly different at $P=0.05$ according to the least significant difference test.

${ }^{\mathrm{z}}$ 1991: 1 = first spray, at growth stage (GS) 4.0; $2=$ second spray, at GS 5.5; and $3=$ third spray, at GS 6.8. 1992: $2=$ second spray, at GS 4.0; $3=$ third spray, at GS 5.5; and 4 = fourth spray, at GS 7.0. 1993: 1 = first spray, 7 to 13 days before second spray; $2=$ second spray, just before detasseling; and 3 $=$ third spray, just after detasseling. 
seed company or grower should be able to detect disease and predict the development of epidemics on the basis of past, current, and predicted weather patterns.

Choice of the fungicide to apply is important; however, the level of net returns will depend on other factors, such as fungicide cost, number and frequency of applications, and disease intensity and growth stage at which fungicide sprays are initiated. In our study, copper thallate used alone did not result in profitable economic returns at most experimental sites; we did not test the efficacy of copper thallate applied as a tank mix with other fungicides. In addition, copper thallate was not tested in 1992 and 1993, when disease levels were considerably higher than those in 1990 and 1991.

Our model assumes that fungicides are applied by commercial applicators. This occurs with contracts in which the company accepts the responsibility of applying fungicides but not with contracts in which the responsibility and costs rest with the grower. We did not attempt an economic analysis in which the grower assumes some costs for fungicides. When fungicideapplication equipment needs to be purchased, the cost can easily be added to the $E_{\mathrm{i}}$ (increased expenses) component of the model with the appropriate adjustment made in the fungicide application cost $(a)$ component. When fungicide-application equipment is purchased, net returns may initially be less than our estimates. Because contracts vary among companies and even within the same company, our model can be easily adapted to accommodate most seed company-grower contracts. The model does not take into consideration the market supply of various genotypes. If there is a large carryover of some genotypes, overproduction of these genotypes will not result in salable seed.

Factors that might influence diseasecontrol decisions by the seed company or grower include knowledge of economic thresholds, cropping histories, availability of disease forecasts, aversion of the farmer and the seed company to risk, credit availability, futures crop prices, and disease- control alternatives. More research is required to gain information on these factors in hybrid corn seed production. Such information and the identification of high-risk areas for plant disease epidemics would benefit seed companies and growers by helping them to make improved pest-man-agement decisions regarding whether or not to use fungicides.

\section{ACKNOWLEDGMENTS}

We thank M. Duffy, Department of Economics, Iowa State University, for advice on economic analysis and P. N. Hinz, Department of Statistics, Iowa State University, for advice on statistical analysis. We also thank C. Fish and T. Kemper, Pioneer Hi-Bred International, Toledo, IA; W. Houser, Pioneer Hi-Bred International, Marengo, IA; D. Hoffman, ICI Seeds, Coon Rapids, IA; and T. Primus, Lynks Seeds Inc., Marshalltown, IA, for their cooperation. We are especially indebted to M. Gleason and G. Munkvold, Department of Plant Pathology, Iowa State University, and $\mathrm{H}$. Scherm, Department of Plant Pathology, University of Georgia (formerly Iowa State University) for critical reading of the manuscript.

\section{LITERATURE CITED}

1. Ayers, J. E., Nelson, R. R., Castor, L. L., and Blanco, M. H. 1976. Yield loss in corn caused by Helminthosporium maydis race T. Plant Dis. Rep. 60:331-335.

2. Bergstrom, G. C. 1991. Fungicide Benefits Assessment. Field Crops North. National Agricultural Pesticide Impact Assessment Program (NAPIAP). Ohio State University, Columbus.

3. Bourdot, G. W., and Saville, D. J. 1988. The economics of herbicide use in cereal crops in New Zealand. N.Z. J. Exp. Agric. 16:201-207.

4. Bowen, K. L., and Pedersen, W. L. 1988. Effects of propiconazole on Exserohilum turcicum in laboratory and field studies. Plant Dis. 72:847-850.

5. Bowen, K. L., and Pedersen, W. L. 1988. Effects of northern leaf blight and detasseling on yields and yield components of corn inbreds. Plant Dis. 72:952-956.

6. Carlson, G. A., and Main, C. E. 1976. Economics of disease loss management. Annu. Rev. Phytopathol. 14:381-403.

7. Edwards, C. R. 1992. Seed Corn Pest Management Manual for the Midwest. Cooperative Extension Service and Departments of Botany, Plant Pathology, and Entomology, Purdue University, West Lafayette, IN.

8. Fry, W. E. 1978. Quantification of general resistance of potato cultivars and fungicide effects for integrated control of potato late blight. Phytopathology 68:1650-1655.

9. Hanway, J. J. 1963. Growth stages of corn (Zea mays L.). Agron. J. 55:487-491.
10. James, C. 1971. A manual of assessment keys for plant diseases. Can. Dep. Agric. Publ. 1458.

11. Johnson, K. B. 1987. Defoliation, disease, and growth: A reply. Phytopathology 77:1495-1497.

12. Martinson, C. A., Wegulo, S. N., Rivera-C., J. M., and Nutter, F. W., Jr. 1994. Fungicidal spray program for seed corn production. Pages 71-79 in: Proc. Annu. Corn Sorghum Res. Conf., 49th. D. Wilkinson, ed. American Seed Trade Association, Washington, DC.

13. Munkvold, G. P., and Yang, X. B. 1995. Crop damage and epidemics associated with 1993 floods in Iowa. Plant Dis. 79:95-101.

14. Nutter, F. W., Jr., and Littrell, R. H. 1995. Relationships between defoliation, canopy reflectance, and pod yield in the peanut-late leaf spot pathosystem. Crop Prot. 15:135-142.

15. Nutter, F. W., Jr., Teng, P. S., and Royer, M. H. 1993. Terms and concepts for yield, crop loss, and disease thresholds. Plant Dis. 77: 211-215.

16. Pataky, J. K. 1987. Quantitative relationships between sweet corn yield and common rust, Puccinia sorghi. Phytopathology 77:1066-1071.

17. Pataky, J. K., and Eastburn, D. M. 1993. Comparing partial resistance to Puccinia sorghi and applications of fungicides for controlling common rust on sweet corn. Phytopathology 83:1046-1051.

18. Reifschneider, F. J. B., and Arny, D. C. 1983. Yield loss of maize caused by Kabatiella zeae. Phytopathology 73:607-609.

19. Rivera-Canales, J. M. 1993. Yield losses, chemical control, and epidemiology of fungal leaf blights on seed corn in Iowa. Ph.D. diss. Abstract microfilm order no. ISU 1993 R525. Iowa State University, Ames.

20. Shaner, G., and Finney, R. E. 1977. The effect of nitrogen fertilization on the expression of slow-mildewing resistance in Knox wheat. Phytopathology 67:1051-1056.

21. Shaw, D. J., Howard, W. H., and Martin, L. J. 1989. Costs, prices, and contracts in the U.S. and Canadian seed corn industries. University of Guelph, Guelph, Ontario, Canada.

22. Steel, R. G. D., Torrie, J. H., and Dickey, D. A. 1997. Principles and Procedures of Statistics. A Biometrical Approach. McGrawHill, New York.

23. Sumner, D. R., Doupnik, B., Jr., and Boosalis, M. G. 1981. Effects of reduced tillage and multiple cropping on plant diseases. Annu. Rev. Phytopathol. 19:167-187.

24. Ward, J. M. J., Laing, M. D., and Rijkenberg, F. H. J. 1997. Frequency and timing of fungicide applications for the control of gray leaf spot in maize. Plant Dis. 81:41-48.

25. Wych, R. D. 1988. Production of hybrid seed corn. Pages 565-607 in: Corn and Corn Improvement. 3rd ed. American Society of Agronomy, Madison, WI. 